Article

\title{
Biotransformation of Bicyclic Halolactones with a Methyl Group in the Cyclohexane Ring into Hydroxylactones and Their Biological Activity
}

\author{
Katarzyna Wińska ${ }^{1, *}$, Małgorzata Grabarczyk ${ }^{1}$, Wanda Mączka ${ }^{1}$, Barbara Żarowska ${ }^{2}$, \\ Gabriela Maciejewska ${ }^{3}$, Katarzyna Dancewicz ${ }^{4}$, Beata Gabryśs ${ }^{4}$, Antoni Szumny ${ }^{1}$ and \\ Mirosław Anioł ${ }^{1}$ \\ 1 Department of Chemistry, Wrocław University of Environmental and Life Sciences, Norwida 25, \\ 50-375 Wrocław, Poland; magrab@onet.pl (M.G.); wanda_m19@o2.pl (W.M.); antjasz@o2.pl (A.S.); \\ miroslaw.aniol@up.wroc.pl (M.A.) \\ 2 Department of Biotechnology and Food Microbiology, Wrocław University of Environmental and Life \\ Sciences, Chełmońskiego 37/41, 51-630 Wrocław, Poland; barbara.zarowska@up.wroc.pl \\ 3 Faculty of Chemistry, Wroclaw University of Technology, Wybrzeze Wyspianskiego 27, 50-370 Wroclaw, \\ Poland; gabriela.maciejewska@pwr.edu.pl \\ 4 Department of Botany and Ecology, University of Zielona Gora, Szafrana 1, 65-516 Zielona Gora, Poland; \\ k.dancewicz@wnb.uz.zgora.pl (K.D.); b.gabrys@wnb.uz.zgora.pl (B.G.) \\ * Correspondence: katarzyna.winska@up.wroc.pl; Tel.: +48-71-320-5213
}

Academic Editor: Derek J. McPhee

Received: 15 September 2016; Accepted: 28 October 2016; Published: 31 October 2016

\begin{abstract}
The aim of this study was the chemical synthesis of a series of halo- and unsaturated lactones, as well as their microbial transformation products. Finally some of their biological activities were assessed. Three bicyclic halolactones with a methyl group in the cyclohexane ring were obtained from the corresponding $\gamma, \delta$-unsaturated ester during a two-step synthesis. These lactones were subjected to screening biotransformation using twenty two fungal strains. These strains were tested on their ability to transform halolactones into new hydroxylactones. Among the six strains able to catalyze hydrolytic dehalogenation, only two (Fusarium equiseti, AM22 and Yarrowia lipolytica, AM71) gave a product in a high yield. Moreover, one strain (Penicillium wermiculatum, AM30) introduced the hydroxy group on the cyclohexane ring without removing the halogen atom. The biological activity of five of the obtained lactones was tested. Some of these compounds exhibited growth inhibition against bacteria, yeasts and fungi and deterrent activity against peach-potato aphid.
\end{abstract}

Keywords: lactones; hydrolytic dehalogenation; antimicrobial activity; deterrent activity

\section{Introduction}

Due to their properties, chloro-organic compounds are used in many areas. They are very often applied as antifungal [1,2], antibacterial [3], antifidant [4,5], cytotoxic, and anticancer agents [6]. They are also used as organic solvents, refrigerants and media, dielectrics, pesticides, monomers for the production of plastic materials, and intermediates for organic synthesis [7]. Usually, these compounds are obtained by organic synthesis although they are increasingly being obtained from natural substances too. The compounds are obtained mainly from marine organisms such as red algae, corals or bacteria [8-10]. Longifoliosides A and B, which were isolated from Veronica longifolia, exhibit radical-scavenging activity against nitric oxide, superoxide, and 2,2-diphenyl-1-picrylhydrazyl radicals [11]. Halogened compounds could also be obtained by using the biotransformation method. Four antimicrobial halogenated compounds, bromomethyl- chlamydosporols A, B, chlamydosporol and fusarielin A, were isolated from a culture of Fusarium tricintum. These halogenated chlamydosporol 
analogues were obtained as products of the fermentation of a marine fungus. The transformation process was inducted by the addition of $\mathrm{CaBr}_{2}$ [12]. All the obtained compounds exhibited low antibacterial activity against Staphylococcus aureus, methicillin-resistant $S$. aureus, and multidrug-resistant $S$. aureus.

Isolated from the Australian ascidian Aplidium caelestis brominated natural products were tested against three mammalian cell lines (MCF-7, NFF, and MM96L), but they showed only minor cytotoxicity [13]. The bromotyrosine alkaloid psammaplysin was isolated from the Australian marine sponge Hyattella sp, along with psammaplysin F. These compounds were tested against two different strains of the parasite Plasmodium falciparum (Dd2 and 3D7). The tests showed that one of them, psammaplysin G, inhibited the chloroquine-resistant (Dd2) strain of P. falciparum by $98 \%$ [14].

Despite the interesting biological properties of halogenated organic compounds, in the 60s it was found that they may accumulate in soil or water without being broken down. At high concentrations, these compounds may have a negative impact on living organisms, endangering their health or life. For decades, researchers conducted experiments on the effects of waste on living organisms. It has been proven that halogenated organic compounds can cause endocrine system disorders in humans [15]. Therefore, effective methods for disposing of organic halo compounds have been the subject of research since the middle of the last century. One of the most popular methods is to transform them using filamentous fungi utilizing their ability for hydrolytic dehalogenation. Our team has been conducting studies dealing with halolactone transformations since 1998 [16]. In these studies we have obtained new compounds with interesting biological properties.

\section{Results and Discussion}

Substrates for biotransformation halolactones 3-5 were obtained during the two-step synthesis from the unsaturated ester 1. Firstly, the ester was hydrolyzed to the $\gamma, \delta$-unsaturated acid 2. In the second step, this acid was transformed into the new chloro-3, bromo-4, and known iodolactone 5 . Iodolactone 5 further reacted with DBU giving the unsaturated lactone 6 (Scheme 1).

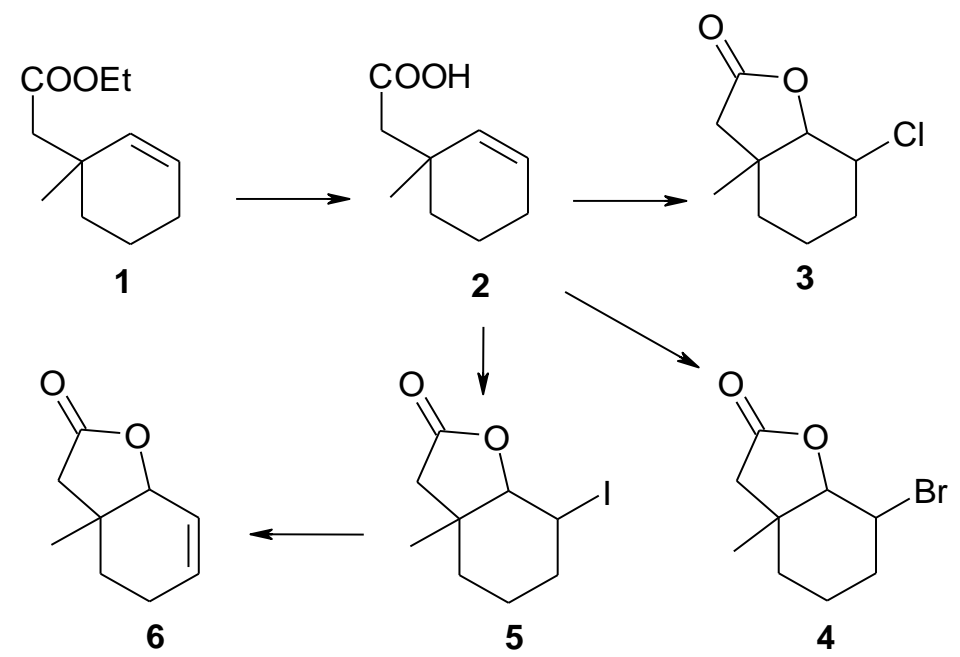

Scheme 1. Synthesis of lactones 3-6.

The structures of these compounds were established on the basis of their spectral data $\left({ }^{1} \mathrm{H}-\mathrm{NMR}\right.$, ${ }^{13} \mathrm{C}-\mathrm{NMR}, \mathrm{COSY}, \mathrm{HMQC}$, and IR) and confirmed by HRMS analysis. In the IR spectra the absorption bands at 1780 (for 3), 1772 (for 4), 1776 (for 5), and 1776 (for 6) $\mathrm{cm}^{-1}$ confirmed the presence of the $\gamma$-lactone ring in the halolactone molecules and the unsaturated lactone. Analysis of the ${ }^{1} \mathrm{H}-\mathrm{NMR}$ spectra of halolactones allowed for the determination of the orientations of protons $\mathrm{H}-1$ and $\mathrm{H}-2$. The signal coming from proton $\mathrm{H}-1$ appeared as a narrow singlet in the case of chloralactone 3 and for 4 and 5 it was a doublet with the small coupling constant ( $5.2 \mathrm{~Hz}$ for 4 and $6.1 \mathrm{~Hz}$ for 5). Such shapes for these signals suggest their equatorial orientation and therefore an axial orientation of the $\mathrm{C}-\mathrm{O}$ bond 
of the lactone ring. Also, a narrow multiplet coming from the H-2 protons indicated their equatorial orientation, which clearly indicated an axial position of the halogen atom. Such observations confirmed that the cyclohexane ring was in a chair conformation. If so, because the $\mathrm{C}-\mathrm{O}$ bond of the lactone ring was in an axial position, the methyl group at carbon C-6 must be in an axial orientation. In the case of unsaturated lactone 6 , the signal coming from proton $\mathrm{H}-1$ looked like a narrow multiplet and indicated its equatorial position. Wide multiplets coming from protons $\mathrm{H}-2$ and $\mathrm{H}-3$ suggested their axial orientation. (Figure 1).
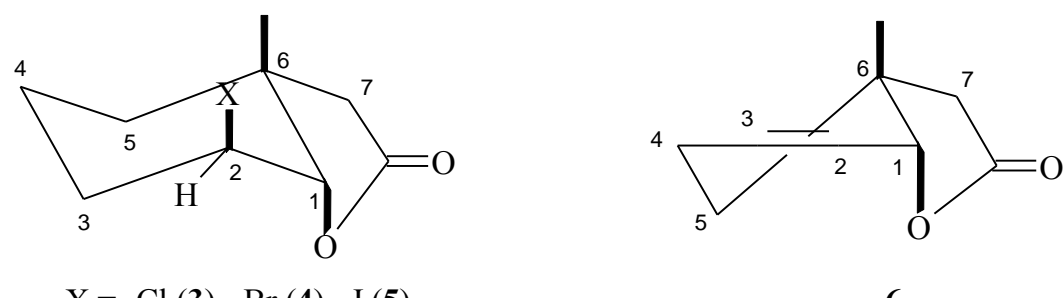

$\mathrm{X}=-\mathrm{Cl}(\mathbf{3}),-\mathrm{Br}(\mathbf{4}),-\mathrm{I}(\mathbf{5})$

6

Figure 1. Structure of lactones 3-6.

Our previous experiences indicated that in most cases halolactones subjected to biotransformation by filamentous fungi strains were converted into hydroxylactones. This reaction-hydrolytic dehalogenation-always proceeded according to a mechanism similar to a $\mathrm{S}_{\mathrm{N}} 2$ substitution. Independently, the structure of the substrate $\mathrm{OH}$ group was always introduced in an equatorial position. Taking this into account, it was interesting to see if in this case the fungal strains would be able to conduct the reaction of hydrolytic dehalogenation, giving new hydroxylactone 7 (Scheme 2). The fourth substrate-unsaturated lactone 6 was also tested for its ability to give any product.

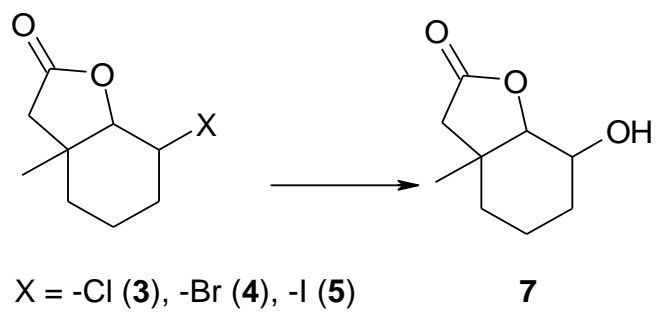

Scheme 2. The expected biotransformation product 7 of halolactones 3-5.

Screening biotransformation was conducted on twenty two fungal strains. The progress of all of these transformations was monitored using standard techniques (TLC and GC). During the present research, one of the chosen microorganisms (Penicillium vermiculatum AM30) generated a different product than the expected one. Taking this observation into consideration, the effects of the screening biotransformation are presented in Tables 1 and 2 .

As it can be seen in the tables, the biotransformed halocompounds were transformed into hydroxycompounds $\mathbf{7 - 1 0}$ by some microorganisms. From the eight Fusarium strains, only Fusarium equiseti AM22 (Table 1, entry 7) proved to be a good catalyst, giving a product in high yield when bromolactone 4 and iodolactone 5 were used as substrates. The second strain which was able to transform these halolactones into hydroxylactone 7 in good yield was Yarrowia lipolytica AM71 (Table 1, entry 18). Some of the other strains (Table 1 , entries $8,9,11,12$ ) were able to create only a small percentage of product. 
Table 1. Results of the screening biotransformation of lactones 3, 4, and 5 after 7 days of incubation (in \% according to GC).

\begin{tabular}{cccccccc}
\hline \multirow{2}{*}{ Entry } & \multirow{2}{*}{ Microorganism } & \multicolumn{5}{c}{ Screening Biotransformation/\% } \\
\cline { 3 - 7 } & $\mathbf{3}$ & $\mathbf{7}$ & $\mathbf{4}$ & $\mathbf{7}$ & $\mathbf{5}$ & $\mathbf{7}$ \\
\hline 1 & Fusarium culmorum AM10 & 100 & - & 100 & - & 100 & - \\
2 & Fusarium avenaceum AM11 & 100 & - & 100 & - & 100 & - \\
3 & Fusarium oxysporum AM13 & 100 & - & 100 & - & 100 & - \\
4 & Fusarium tricinctum AM16 & 100 & - & 100 & - & 100 & - \\
5 & Fusarium semitectum AM20 & 100 & - & 100 & - & 100 & - \\
6 & Fusarium oxysporum AM21 & 100 & - & 100 & - & 100 & - \\
7 & Fusarium equiseti AM22 & 65.4 & 34.6 & 3.3 & $\mathbf{9 6 . 7}$ & 40.0 & $\mathbf{6 0 . 0}$ \\
8 & Fusarium solani AM203 & 86.1 & 13.9 & 76.6 & 23.4 & 74.7 & 25.3 \\
9 & Syncephalastrum racemosum AM105 & 100 & - & 74.0 & 26.0 & 69.9 & 30.1 \\
10 & Absidia coerulea AM93 & 100 & - & 100 & - & 100 & - \\
11 & Absidia cylindrospora AM336 & 100 & - & 75.0 & 25.0 & 86.0 & 14.0 \\
12 & Penicillium camembertii AM83 & 85.3 & 14.7 & 100 & - & 100 & - \\
13 & Penicillium chermesinum AM113 & 100 & - & 100 & - & 100 & - \\
14 & Penicillium frequentans AM351 & 100 & - & 100 & - & 100 & - \\
13 & Aspergillus wenthi AM413 & 100 & - & 100 & - & 100 & - \\
14 & Aspergillus ochraceus AM456 & 100 & - & 100 & - & 100 & - \\
15 & Pleurotus ostreatus AM482 & 100 & - & 100 & - & 100 & - \\
16 & Pleurotus ostreatus AM600 & 100 & - & 100 & - & 100 & - \\
17 & Mucor hiemalis AM450 & 100 & - & 100 & - & 100 & - \\
18 & Yarrowia lipolytica AM71 & 75.5 & 27.4 & 13.3 & $\mathbf{8 6 . 7}$ & 40.7 & $\mathbf{5 9 . 3}$ \\
19 & Rhodotorula marina AM77 & 100 & - & 100 & - & 100 & - \\
\hline
\end{tabular}

Numbers in bold mean they are the best results of biotransformation.

Table 2. Results of the screening biotransformation of lactones 3, 4, and 5 after 7 days of incubation (in \% according to GC).

\begin{tabular}{cccccccc}
\hline \multirow{2}{*}{ Entry } & \multirow{2}{*}{ Microorganism } & \multicolumn{5}{c}{ Screening Biotransformation/\% } \\
\cline { 3 - 7 } & Penicillium vermiculatum AM30 & $\mathbf{3}$ & $\mathbf{8}$ & $\mathbf{4}$ & $\mathbf{9}$ & $\mathbf{5}$ & $\mathbf{1 0}$ \\
\hline 1 & & 30.7 & 79.1 & 20.9 & 65.4 & 34.6 \\
\hline
\end{tabular}

It is worth noticing that Penicillium camembertii AM83 transformed only one of the halolactones. During the screening biotransformation it turned out that Penicillium vermiculatum AM30 strain (Table 2, entry 1) was able to produce different products than the other microorganisms. This was very surprising because till now we had not observed any products when this strain was used for biotransformation. It turned out that $P$. vermiculatum produced new hydroxyhalolactones 8-10. These lactones were obtained as a product of hydroxylation on carbon C-5 without the removal of the halogen atom from carbon C-2 (Scheme 3).<smiles>[X]C1CCCC2(C)CC(=O)OC12</smiles><smiles>[X]C1CCC(O)C2(C)CC(=O)OC12</smiles>

$$
\mathrm{X}=-\mathrm{Cl}(\mathbf{3} \text { or } \mathbf{8}),-\mathrm{Br}(\mathbf{4} \text { or } \mathbf{9}),-\mathrm{I}(\mathbf{5} \text { or } \mathbf{1 0})
$$

Scheme 3. The products of biotransformation of halolactones 3-5 by Penicillium vermiculatum AM30.

As mentioned earlier, unsaturated lactone 6 was also checked for its ability to give any product. Unfortunately none of the tested microorganisms were able to convert this substrate. 
Since the aim of the present study was to obtain and characterize the structures of the biotransformation productsf-hydroxylactone $\mathbf{7}$ and also hydroxy-halolactones $\mathbf{8 - 1 0}$-preparative scale biotransformations were performed in the next step. The best strains selected during the screening biotransformation were used for this purpose. The results of this are shown in Figure 2.

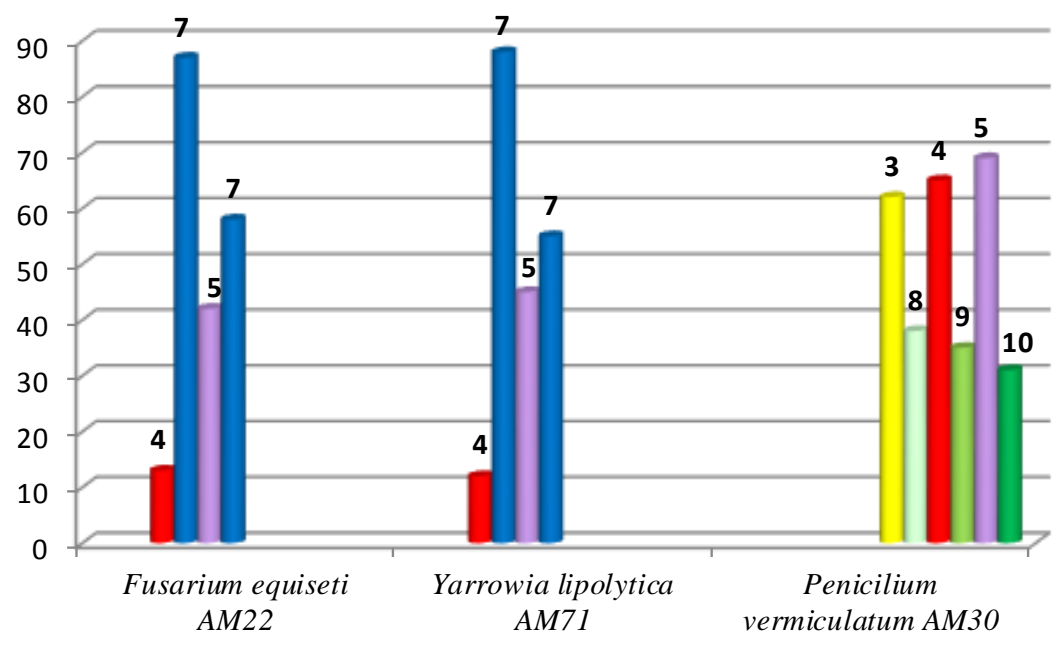

Figure 2. Results of preparative scale biotransformations carried out on halolactones 3-5 (by GC).

Two strains-F. equiseti and Y. lipolytica-were able to convert lactones 4, 5 into the same product-hydroxylactone 7 . The better substrate was bromolactone 4 , which was transformed into a product with a very good degree of conversion $(87 \%$ and $88 \%)$. In the case of iodolactone 5 the product was created with a lower conversion $(55 \%-58 \%)$. The third strain P. vermiculatum led to hydroxyhalolactones with low efficiency, due to a narrow degree of conversion of the substrates (between $31 \%$ and $38 \%$ ). For this reason it was only possible to check their chemical properties.

Analysis of ${ }^{1} \mathrm{H}-\mathrm{NMR}$ spectra of hydroxylactone 7 proved that the chair conformation of the cyclohexane ring was retained. The narrow signal coming from proton $\mathrm{H}-1$ indicated its equatorial position. It means that the $\mathrm{C}-\mathrm{O}$ bond of the lactone ring is located in an axial position, as in the substrates. The wide multiplet coming from proton H-2 suggested its axial orientation and consequently an equatorial position of the hydroxy group (Figure 3).

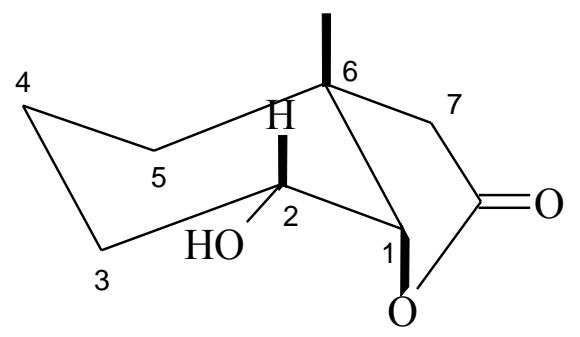

Figure 3. Structure of hydroxylactone 7.

The hydrolytic dehalogenation reaction occurred similarly to a $\mathrm{S}_{\mathrm{N}} 2$ mechanism in every case. Moreover the hydroxy group was always introduced in the equatorial position in the cyclohexane ring. When a halogen atom occupied an equatorial position the simultaneous change of the conformation of the cyclohexane ring was observed during the reaction of hydrolytic dehalogenation $[16,17]$. When the halogen atoms occupied an axial position and the equatorial position was free, conformational change of the cyclohexane ring was not observed [18]. Because the halogen atom was in an axial position as described in the situation here, the conformation of the cyclohexane ring had not changed. 
Analysis of ${ }^{1} \mathrm{H}-\mathrm{NMR}$ spectra of the hydroxyhalolactones 8-10 proved that the halolactone ring structure was retained. Such a conclusion was evidenced by the narrow doublet coming from proton $\mathrm{H}-1(J=3.2 \mathrm{~Hz}$ for $8, J=3.5 \mathrm{~Hz}$ for 9 , and $J=4.0 \mathrm{~Hz}$ for 10$)$ and the wide multiplet coming from proton $\mathrm{H}-2$, indicating their equatorial and axial position, respectively. Also the wide doublet of doublets $(J=10.7 \mathrm{~Hz}$ for $8, J=10.3 \mathrm{~Hz}$ for 9 , and $J=9.1 \mathrm{~Hz}$ for 10$)$ coming from the hydroxy group at carbon C-5 suggested its axial orientation and an equatorial position of the hydroxy group (Figure 4).

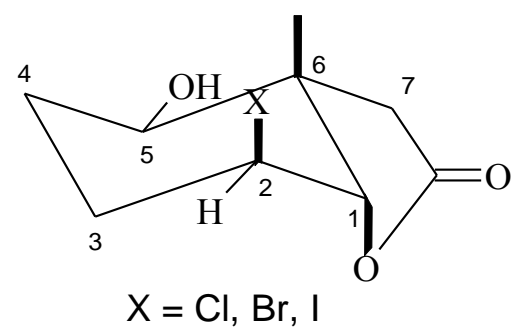

Figure 4. Structure of hydroxy-halolactone 8-10.

In the next step, the isolated yield, enantiospecificity, and optical purity of the hydroxylactone $\mathbf{7}$ and the hydroxyhalolactones $\mathbf{8 - 1 0}$ obtained during all the preparative biotransformations were determined. The results of shown in Table 3.

Table 3. Results of the preparative biotransformations of lactones 3-5.

\begin{tabular}{ccccccc}
\hline Substrate & Strain & Product & $\begin{array}{c}\text { Isolated } \\
\text { Yield g/\% }\end{array}$ & $\begin{array}{c}\text { Enatiomeric } \\
\text { Excess (\%) }\end{array}$ & $\begin{array}{c}\text { Optical } \\
\text { Rotation }[\boldsymbol{\alpha}]_{D}^{\mathbf{2 0}}\end{array}$ & $\begin{array}{c}\text { Concentration in } \\
\mathbf{C H} \mathbf{~ C l}(\mathbf{g} / \mathbf{1 0 0} \mathbf{~ m L})\end{array}$ \\
\hline $\mathbf{3}$ & P. vermiculatum AM30 & $\mathbf{8}$ & $0.0098 / 9.0$ & 7.6 & +5.404 & 0.48 \\
$\mathbf{4}$ & F. equiseti AM22 & $\mathbf{7}$ & $0.028 / 38.4$ & 10.7 & -6.762 & 0.56 \\
$\mathbf{4}$ & Y. lipolytica AM71 & $\mathbf{7}$ & $0.021 / 28.8$ & 5.8 & -6.244 & 0.62 \\
$\mathbf{4}$ & P. vermiculatum AM30 & $\mathbf{9}$ & $0.0114 / 10.7$ & 1.6 & +0.645 & 0.78 \\
$\mathbf{5}$ & F. equiseti AM22 & $\mathbf{7}$ & $0.016 / 26.3$ & 27.0 & -17.886 & 0.44 \\
$\mathbf{5}$ & Y. lipolytica AM71 & $\mathbf{7}$ & $0.024 / 40.2$ & 52.9 & -31.214 & 0.51 \\
$\mathbf{5}$ & P. vermiculatum AM30 & $\mathbf{1 0}$ & $0.015 / 14.2$ & 5.5 & +4.108 & 0.67 \\
\hline
\end{tabular}

Optical rotation was measured for $589 \mathrm{~nm}$ and temperature $20^{\circ} \mathrm{C}$.

In all cases the (-)-isomer of hydroxylactone 7 was formed preferentially. When bromolactone 4 was used as a substrate, the enantiomeric excesses did not exceed $11 \%$. When hydroxylactone 7 was created from iodolactone 5 these values were much better, amounting to $52.9 \%$ and $27 \%$. In the case of hydroxyhalolactones 8-10 the (+)-isomer was preferentially created, but the enantiomeric excesses did not exceed $7.6 \%$.

Another aim in this research work was the verification of the biological properties of the obtained compounds. The obtained synthetic halolactones $\mathbf{3 - 6}$, as well as the obtained microbiologically formed hydroxylactone 7, were examined for their ability to inhibit the growth of some bacteria, yeast, and fungal strains. Statistical analysis was performed for the results of microbiological tests. Calculations were made for each of the strains separately. Control and further compounds were treated as test variability. The underlying assumption was the null hypothesis that the mean for the control and individual substances do not differ. The hypothesis was verified by a F-Senedecora test at the significance level of $p=0.01$. It has been shown that for each strain averages are significantly different. Then Dunnett's test was checked, in which means are significantly different from the average for the control. The results of this test are presented in Table 4. 
Table 4. Antimicrobial activity of lactones 3-7. Statistics on a completely randomized design were determined using the one-way analysis of variance (ANOVA) procedure at a level of significance set at $p=0.010$. A comparison of average growth OD microorganisms relative to the control by Dunnett's test. Underlined numbers mean the average was significantly different from control.

\begin{tabular}{|c|c|c|c|c|c|c|c|}
\hline & Strain & E. coli & S. aureus & P. fluorescens & C. albicans & F. avenaceum & A. niger \\
\hline \multirow{2}{*}{ Control } & Lag-phase [h] & 5 & 16 & 8 & 14.5 & 15.5 & 7.5 \\
\hline & $\Delta \mathrm{OD} \pm \mathrm{SD}$ & $1.29 \pm 0.07$ & $1.09 \pm 0.05$ & $1.36 \pm 0.07$ & $1.14 \pm 0.05$ & $1.18 \pm 0.04$ & $1.94 \pm 00.6$ \\
\hline \multirow{2}{*}{3} & Lag-phase [h] & 9 & - & 14.5 & 21 & 35 & 13 \\
\hline & $\Delta \mathrm{OD} \pm \mathrm{SD}$ & $\underline{0.29 \pm 0.04}$ & $\underline{0}$ & $\underline{1.05 \pm 0.06}$ & $1.11 \pm 0.04$ & $\underline{1.40 \pm 0.05}$ & $1.48 \pm 0.05$ \\
\hline \multirow{2}{*}{4} & Lag-phase [h] & 18 & - & 16 & 29 & - & 13 \\
\hline & $\Delta \mathrm{OD} \pm \mathrm{SD}$ & $\underline{0.43 \pm 0.05}$ & $\underline{0}$ & $1.08 \pm 0.04$ & $1.18 \pm 0.04$ & $\underline{0}$ & $\underline{1.02 \pm 0.04}$ \\
\hline \multirow{2}{*}{5} & Lag-phase [h] & 9 & $\overline{23}$ & 13 & 15 & $\overline{38}$ & 9 \\
\hline & $\Delta \mathrm{OD} \pm \mathrm{SD}$ & $\underline{0.32 \pm 0.03}$ & $\underline{0.37 \pm 0.04}$ & $\underline{0.95 \pm 0.03}$ & $\underline{0.95 \pm 0.03}$ & $\underline{0.71 \pm 0.04}$ & $1.97 \pm 0.05$ \\
\hline \multirow{2}{*}{6} & Lag-phase [h] & 9 & - & $\frac{14}{14}$ & 21 & 32.5 & 11.5 \\
\hline & $\Delta \mathrm{OD} \pm \mathrm{SD}$ & $\underline{0.27 \pm 0.03}$ & 0 & $1.32 \pm 0.02$ & $\underline{0.77 \pm 0.02}$ & $\underline{1.80 \pm 0.06}$ & $1.33 \pm 0.07$ \\
\hline \multirow{2}{*}{7} & Lag-phase [h] & 5 & 36 & 12 & 19.5 & 14.5 & 7.5 \\
\hline & $\Delta \mathrm{OD} \pm \mathrm{SD}$ & $\underline{0.57 \pm 0.05}$ & $\underline{0.62 \pm 0.04}$ & $\underline{1.15 \pm 0.04}$ & $\underline{1.99 \pm 0.06}$ & $1.87 \pm 0.07$ & $1.94 \pm 0.06$ \\
\hline
\end{tabular}

OD—Optical Density; OD was measured for $\lambda 550 \mathrm{~nm}$; SD—Standard Deviation.

The group of microorganisms exhibiting the greatest growth-inhibition by the test compounds were bacteria. In the case of the Escherichia coli strain, all lactones caused inhibition of the bacterial growth. This is a very interesting result, because so far the compounds which tested by us were relatively inactive to this strain. Lactones 3, 4, and 6 completely inhibited the growth of the Staphylococcus aureus strain. Compounds $\mathbf{5}$ and $\mathbf{7}$ also affected the growth of this strain of bacteria causing considerable extension phase adaptive (20-36 h) and a slight increase in the biomass expressed as $\triangle \mathrm{OD}$ in the range of $0.37-0.62$. It is worth noting that in the culture of the Pseudomonas fluorescens strain, conducted in the presence of 5, diauxic growth was observed. The same effect was observed earlier for the E. coli strain and the C. albicans strain [19]. This phenomenon was also reported by other authors $[20,21]$.

In the case of the C. albicans strain, lactone 7 stimulated the growth of these yeasts resulting in the growth of biomass, $\triangle \mathrm{OD}$ was equal to 1.99 , whereas the control yeast culture's $\Delta \mathrm{OD}$ value was 1.14. A similar effect of the stimulation of growth occurred in the case of a strain of Fusarium avenaceum. In this case compounds 6 and 7 produced an increase in the biomass of 0.62-0.69 compared to the control culture. Lactone 5 inhibited growth in the Fusarium avenaceum strain. Lactone 4 completely inhibited the growth of the Fusarium avenaceum. Other biological tests were conducted to determine the deterrent activity of lactones 3-7 against peach-potato aphid Myzus persicae. The results of this experiment are presented in Table 5.

Table 5. Deterrent activity of lactones 3-7. Numbers for C (= control) and T (= treated) represent the mean number $( \pm \mathrm{SE})$ of aphids that settled on the control or the treated leaf (choice-test) $1 \mathrm{~h}, 2 \mathrm{~h}$, and $24 \mathrm{~h}$ after exposure. $p$-significance level (Student $t$-test)—significant differences $(p<0.05)$ between the number of aphids settled on either leaf are underlined.

\begin{tabular}{cccccccccc}
\hline & \multicolumn{3}{c}{$\mathbf{1} \mathbf{h}$} & \multicolumn{1}{c}{$\mathbf{2} \mathbf{h}$} & \multicolumn{3}{c}{$\mathbf{2 4} \mathbf{h}$} \\
\cline { 2 - 10 } & $\mathbf{C}$ & $\mathbf{T}$ & $\boldsymbol{p}$ & $\mathbf{C}$ & $\mathbf{T}$ & $\boldsymbol{p}$ & $\mathbf{C}$ & $\mathbf{T}$ & $\boldsymbol{p}$ \\
\hline $\mathbf{3}$ & $2.8( \pm 0.8)$ & $1.0( \pm 0.3)$ & 0.0615 & $2.5( \pm 0.6)$ & $1.6( \pm 0.3)$ & 0.2189 & $6.0( \pm 1.0)$ & $4.5( \pm 1.5)$ & 0.4168 \\
$\mathbf{4}$ & $7.6( \pm 1.1)$ & $2.5( \pm 0.5)$ & $\underline{0.0007}$ & $5.5( \pm 1.7)$ & $2.9( \pm 0.7)$ & 0.1791 & $8.5( \pm 1.5)$ & $3.6( \pm 0.8)$ & $\underline{0.0116}$ \\
$\mathbf{5}$ & $3.3( \pm 0.8)$ & $0.9( \pm 0.3)$ & $\underline{0.0106}$ & $3.4( \pm 0.5)$ & $0.9( \pm 0.5)$ & $\underline{0.0028}$ & $6.3( \pm 0.9)$ & $3.6( \pm 0.8)$ & $\underline{0.0470}$ \\
$\mathbf{6}$ & $9.6( \pm 1.3)$ & $3.4( \pm 1.3)$ & $\underline{0.0035}$ & $10.6( \pm 1.5)$ & $4.3( \pm 1.3)$ & $\underline{0.0067}$ & $7.8( \pm 1.8)$ & $6.1( \pm 1.5)$ & 0.4972 \\
$\mathbf{7}$ & $1.8( \pm 0.7)$ & $2.6( \pm 1.0)$ & 0.4951 & $3.0( \pm 1.0)$ & $2.9( \pm 0.9)$ & 0.9285 & $5.6( \pm 0.8)$ & $4.5( \pm 1.0)$ & 0.3996 \\
\hline
\end{tabular}

Among the tested lactones, bromolactone 4 and iodolactone 5 showed high and persistent deterrent properties. The application of these compounds caused the avoidance of plants by aphids as soon as $1 \mathrm{~h}$ after exposure and the effect persisted at least until the 24th hour of the experiment. However, the level of activity of 5 tended to subside over the course of time. The other lactones, 
chlorolactone 3 and the unsaturated lactone 6 also showed deterrent capacity. The relatively strong deterrent effect of 6 ceased before the 24th hour after application. Hydroxylactone 7 initially expressed a tendency to attract aphids, but this tendency reversed over the course of time (Table 5, Figure 5). The changes in the deterrence potency of various low molecular terpenoid lactones are typical for this group of compounds. The switch from attractant to deterrent properties or otherwise was found in the case of piperitone-derived saturated lactones, halolactones and hydroxylactones [22,23]. Literature data [24] suggest that the high enantiomeric excess affected the deterrent activity of the aphids. The halolactones 3-5 presented here were the racemic mixtures. In the case of hydroxylactone 7, ee values were not very high. Because of that, it is impossible to determine any influence of the enantiomeric excesses of these lactones on the deterrent activity of the aphids.

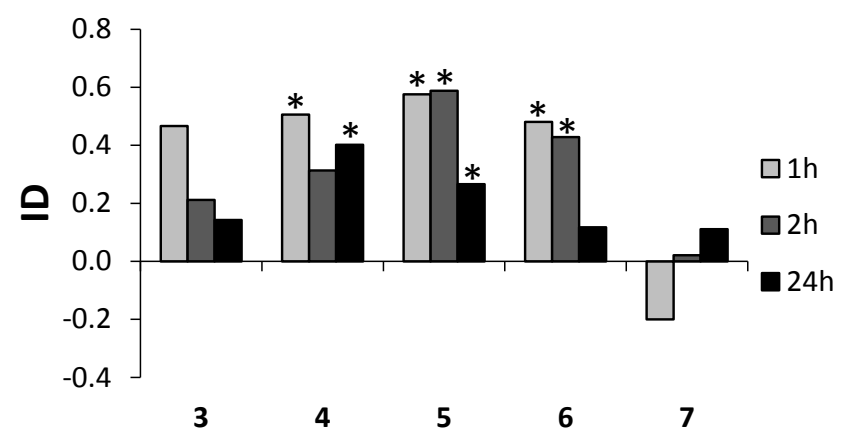

Figure 5. Effect of lactones 3-7 on settling preferences of Myzus persicaein the choice test. ID-index of deterrence, ${ }^{*} p<0.05$ (according to statistical analysis using Student $t$-test) (STATISTICA (data analysis software system), version 10, 2014, StatSoft, Inc., Tulsa, OK, USA, www.statsoft.com).

\section{Experimental Section}

\subsection{General Information}

TLC was performed on silica gel-coated aluminium plates (DC-Alufolien Kieselgel 60 F254, Merck: Darmstadt, Germany) using a mixture of hexane and acetone in various ratios. Preparative column chromatography was performed on the silica gel (Kieselgel 60, 230-400 mesh ASTM, Merck) with a mixture of hexane and acetone (for unsaturated lactone 6 and biotransformation products hexane-acetone 3:1, for halolactones 3-5 hexane-acetone 6:1) as eluents. GC analysis was carried out on an Agilent Technologies 6890N instrument (Varian, Agilent Technologies, Santa Clara, CA, USA) instrument using a DB-17 column (cross-linked methyl silicone gum, $30 \mathrm{~m} \times 0.32 \mathrm{~mm} \times 0.25 \mu \mathrm{m})$. The enantiomeric compositions of the products obtained during the biotransformation were determined by GC analysis using the chiral column CP-cyclodextrin-B-110 $(30 \mathrm{~m} \times 0.25 \mathrm{~mm} \times 0.25 \mu \mathrm{m})$ (Supelco, Bellefonte, PA, USA) under the following conditions: injector $200{ }^{\circ} \mathrm{C}$, detector (FID) $200{ }^{\circ} \mathrm{C}$, column temperature $120{ }^{\circ} \mathrm{C}$, hold $105 \mathrm{~min}$; ramp $120-135^{\circ} \mathrm{C}$ at a rate $1{ }^{\circ} \mathrm{C} / \mathrm{min}$, ramp $135-200{ }^{\circ} \mathrm{C}$ at a rate $20^{\circ} \mathrm{C} / \mathrm{min}$ and hold $1 \mathrm{~min}$ at $200{ }^{\circ} \mathrm{C}$ (for hydroxylactone $7 \mathrm{Rt}$ : (+) $115 \mathrm{~min},(-) 116 \mathrm{~min}$ ) and injector $200^{\circ} \mathrm{C}$, detector (FID) $200^{\circ} \mathrm{C}$, column temperature $140{ }^{\circ} \mathrm{C}$, ramp $140-160{ }^{\circ} \mathrm{C}$ at a rate $0.5^{\circ} \mathrm{C} / \mathrm{min}$, ramp $160-200{ }^{\circ} \mathrm{C}$ at a rate $20^{\circ} \mathrm{C} / \mathrm{min}$ and hold $1 \mathrm{~min}$ at $200{ }^{\circ} \mathrm{C}$ (for hydroxyhalolactones: $8 \mathrm{Rt}$ : (-) $36 \mathrm{~min},(+) 38 \mathrm{~min}$; $9 \mathrm{Rt}$ : (-) $27 \mathrm{~min},(+) 29 \mathrm{~min} ; 10 \mathrm{Rt}:(-) 30 \mathrm{~min}$, (+) $32 \mathrm{~min})$.

The molar masses of the obtained compounds were confirmed by high resolution mass spectrometry analysis using a Waters LCT Premier XE instrument (ESI ionisation) (Waters Division, Milford, MA, USA).

${ }^{1} \mathrm{H}-\mathrm{NMR}$ spectra were recorded in a $\mathrm{CDCl}_{3}$ solution on a Bruker Avance ${ }^{\mathrm{TM}} 600 \mathrm{MHz}$ spectrometer (Bruker, Billerica, MA, USA). Chemical shifts are reported in reference to the residual solvent signal $\left(\delta_{\mathrm{H}}=7.26\right)$. IR spectra were recorded on a IR300 FT-IR spectrometer (Thermo-Nicolet, Waltham, 
MA, USA). Optical rotations were determined on a P-2000 polarimeter (Jasco, Easton, PA, USA) in chloroform solutions, with concentrations denoted in $\mathrm{g} / 100 \mathrm{~mL}$. The melting points were determined on a Boetius apparatus. The refractive index was measured on a Carl Zeiss Abbe and Pulfrich refractometer (Jena, Germany).

\subsection{Synthesis of Substrates}

Unsaturated ester 1 was hydrolyzed into the known [25] $\gamma, \delta$-unsaturated acid 2 according to the known method [26]. This acid was then converted into the new chloro-3, bromo-4, and known [25] iodolactone 5 according to the procedure described earlier [27]. Iodolactone 5 was then used to obtain unsaturated lactone $\mathbf{6}$. Here we present the synthesis and spectral data of compounds 3-6, more Data can be found in the Supplementary Materials. This data will be useful in studying the relationship between the structures of the substrates and their interaction with microorganisms.

2-Chloro-6-methyl-9-oxabicyclo[4.3.0]nonan-8-one (3). Chlorolactonization of acid 2 (2.5 g, $0.016 \mathrm{~mol})$, according to the procedure of [26] gave $1.6 \mathrm{~g}$ (76\%) of chlorolactone 3 with the following physical and spectral properties: m.p. $=42-43{ }^{\circ} \mathrm{C},{ }^{1} \mathrm{H}-\mathrm{NMR}\left(600 \mathrm{MHz}, \mathrm{CDCl}_{3}\right): 1.34\left(\mathrm{~s}, 3 \mathrm{H}, \mathrm{CH}_{3}-9\right), 1.49-1.51(\mathrm{~m}$, $1 \mathrm{H}$, one of $\left.\mathrm{CH}_{2}-4\right), 1.53-1.57\left(\mathrm{~m}, 1 \mathrm{H}\right.$, one of $\left.\mathrm{CH}_{2}-5\right), 1.59-1.63\left(\mathrm{~m}, 1 \mathrm{H}\right.$, one of $\left.\mathrm{CH}_{2}-5\right), 1.83-1.85(\mathrm{~m}$, $2 \mathrm{H}$, one of $\mathrm{CH}_{2}-4$ and one of $\left.\mathrm{CH}_{2}-3\right), 2.05-2.09\left(\mathrm{~m}, 1 \mathrm{H}\right.$, one of $\left.\mathrm{CH}_{2}-3\right), 2.31(\mathrm{~d}, J=16.9 \mathrm{~Hz}, 1 \mathrm{H}$, one of $\left.\mathrm{CH}_{2}-7\right), 2.42\left(\mathrm{~d}, \mathrm{~J}=16.9,1 \mathrm{H}\right.$, one of $\left.\mathrm{CH}_{2}-7\right), 4.18(\mathrm{~m}, 1 \mathrm{H}, \mathrm{H}-2), 4.22(\mathrm{~m}, 1 \mathrm{H}, \mathrm{H}-1),{ }^{13} \mathrm{C}-\mathrm{NMR}(151 \mathrm{MHz}$, $\mathrm{CDCl}_{3}$ ): 17.62 (C-4), 25.36 (C-9), 30.54 (C-3), 32.92 (C-5), 39.42 (C-1), 42.95 (C-7), 57.02 (C-2), 86.84 (C-1), 175.08 (C-8), IR (KBr, cm $\left.{ }^{-1}\right): 2958,1780,1449,1159,1022,993$, ESIHRMS: calcd for $\mathrm{C}_{9} \mathrm{H}_{13} \mathrm{ClO}_{2}, \mathrm{~m} / z$ $189.0677[\mathrm{M}+\mathrm{H}]^{+}$, found 189.0682 .

2-Bromo-6-methyl-9-oxabicyclo[4.3.0]nonan-8-one (4). After the bromolactonization of $1.7 \mathrm{~g}(0.011 \mathrm{~mol}) \mathrm{of}$ acid 3, according to the known method [26], $1.6 \mathrm{~g}(61 \%)$ of bromolactone 4 was obtained. The physical and spectral data of this product are as follows: m.p. $=49-50{ }^{\circ} \mathrm{C},{ }^{1} \mathrm{H}-\mathrm{NMR}\left(600 \mathrm{MHz}, \mathrm{CDCl}_{3}\right): 1.36(\mathrm{~s}$, $\left.3 \mathrm{H}, \mathrm{CH}_{3}-9\right), 1.51-1.54\left(\mathrm{~m}, 1 \mathrm{H}\right.$, one of $\left.\mathrm{CH}_{2}-4\right), 1.54-1.56\left(\mathrm{~m}, 1 \mathrm{H}\right.$, one of $\left.\mathrm{CH}_{2}-5\right), 1.63-1.67(\mathrm{~m}, 1 \mathrm{H}$, one of $\left.\mathrm{CH}_{2}-5\right), 1.83-1.86\left(\mathrm{~m}, 1 \mathrm{H}\right.$, one of $\left.\mathrm{CH}_{2}-4\right), 1.91-1.96\left(\mathrm{~m}, 1 \mathrm{H}\right.$, one of $\left.\mathrm{CH}_{2}-3\right), 2.16-2.20(\mathrm{~m}, 1 \mathrm{H}$, one of $\left.\mathrm{CH}_{2}-3\right), 2.28\left(\mathrm{~d}, J=16.9 \mathrm{~Hz}, 1 \mathrm{H}\right.$, one of $\left.\mathrm{CH}_{2}-7\right), 2.46\left(\mathrm{~d}, J=16.9,1 \mathrm{H}\right.$, one of $\left.\mathrm{CH}_{2}-7\right), 4.20(\mathrm{~m}, 1 \mathrm{H}, \mathrm{H}-2)$, $4.36(\mathrm{~d}, J=5.2 \mathrm{~Hz}, 1 \mathrm{H}, \mathrm{H}-1),{ }^{13} \mathrm{C}-\mathrm{NMR}\left(151 \mathrm{MHz}, \mathrm{CDCl}_{3}\right): 18.95$ (C-4), 26.10 (C-9), 31.67 (C-3), 32.97 (C-5), 39.86 (C-1), 42.41 (C-7), 48.58 (C-2), 87.42 (C-1), 174.92 (C-8), IR (KBr, cm $\left.{ }^{-1}\right)$ : 2958, 1772, 1448, 1156, 1019, 993, ESIHRMS: calcd for $\mathrm{C}_{9} \mathrm{H}_{13} \mathrm{BrO}_{2}, m / z 233.0172(\mathrm{M}+\mathrm{H})^{+}$, found 233.0177 .

2-Iodo-6-methyl-9-oxabicyclo[4.3.0]nonan-8-one (5). Iodolactonization of $1.8 \mathrm{~g}(0.012 \mathrm{~mol})$ of acid 2, according to the known procedure [26] gave $1.9 \mathrm{~g}(58 \%)$ of iodolactone 5 with the following physical and spectral properties: m.p. $=60-62{ }^{\circ} \mathrm{C},{ }^{1} \mathrm{H}-\mathrm{NMR}\left(600 \mathrm{MHz}, \mathrm{CDCl}_{3}\right): 1.37\left(\mathrm{~s}, 3 \mathrm{H}, \mathrm{CH}_{3}-9\right), 1.50-1.58$ $\left(\mathrm{m}, 2 \mathrm{H}\right.$, one of $\mathrm{CH}_{2}-4$ and one of $\left.\mathrm{CH}_{2}-5\right), 1.70-1.75\left(\mathrm{~m}, 2 \mathrm{H}\right.$, one of $\mathrm{CH}_{2}-4$, and one of $\left.\mathrm{CH}_{2}-5\right), 1.97-2.02$ $\left(\mathrm{m}, 1 \mathrm{H}\right.$, one of $\left.\mathrm{CH}_{2}-3\right), 2.18-2.19\left(\mathrm{~m}, 1 \mathrm{H}\right.$, one of $\left.\mathrm{CH}_{2}-3\right), 2.21\left(\mathrm{~d}, \mathrm{~J}=16.9 \mathrm{~Hz}, 1 \mathrm{H}\right.$, one of $\left.\mathrm{CH}_{2}-7\right), 2.53$ $\left(\mathrm{d}, J=16.9,1 \mathrm{H}\right.$, one of $\left.\mathrm{CH}_{2}-7\right), 4.21(\mathrm{~m}, 1 \mathrm{H}, \mathrm{H}-2), 4.46(\mathrm{~d}, J=6.1 \mathrm{~Hz}, 1 \mathrm{H}, \mathrm{H}-1),{ }^{13} \mathrm{C}-\mathrm{NMR}(151 \mathrm{MHz}$, $\mathrm{CDCl}_{3}$ ): 21.13 (C-4), 25.97 (C-2), 27.21 (C-9), 33.05 (C-5), 34.21 (C-3), 40.15 (C-6), 41.36 (C-7), 89.25 (C-1), 174.73 (C-8), IR (KBr, cm $\left.{ }^{-1}\right)$ : 2956, 1776, 1457, 1149, 987, ESIHRMS: calcd for $\mathrm{C}_{9} \mathrm{H}_{13} \mathrm{IO}_{2}, m / z 281.0033$ $(\mathrm{M}+\mathrm{H})^{+}$, found 281.0038 .

6-Methyl-9-oxabicyclo[4.3.0]non-2-en-8-one (6). Iodolactone 5 (0.25 g, $0.0009 \mathrm{~mol})$ was heated with DBU in toluene for three hours. After standard purification was obtained $0.125 \mathrm{~g}(92 \%)$ of unsaturated lactone 7 with the following physical and spectral properties: colourless oil, ${ }^{1} \mathrm{H}-\mathrm{NMR}(600 \mathrm{MHz}$, CDCl3): 1.19 (s, 3H, CH3-9), 1.56 (dt, $J=13.6$ and $5.5 \mathrm{~Hz}, 1 \mathrm{H}$, one of $\mathrm{CH} 2-5), 1.67$ (ddd, $J=13.6,7.5$ and $6.0 \mathrm{~Hz}, 1 \mathrm{H}$, one of CH2-5), 2.13-2.15 (m, 2H, CH2-4), $2.34(\mathrm{~d}, J=17.1 \mathrm{~Hz}, 1 \mathrm{H}$, one of CH2-7), $2.47(\mathrm{~d}$, $J=17.1,1 \mathrm{H}$, one of $\mathrm{CH} 2-7), 4.30(\mathrm{~m}, 1 \mathrm{H}, \mathrm{H}-1), 5.81-5.84(\mathrm{~m}, 1 \mathrm{H}, \mathrm{H}-2), 6.06-6.10(\mathrm{~m}, 1 \mathrm{H}, \mathrm{H}-3),{ }^{13} \mathrm{C}-\mathrm{NMR}$ (151 MHz, CDCl3): 21.70 (C-4), 23.37 (C-9), 29.38 (C-5), 37.11 (C-6), 41.97 (C-7), 81.08 (C-1), 122.89 (C-2), 133.05 (C-3), 176.28 (C-8), IR (KBr, cm-1): 2963, 1776, 1211, 1154, 989, ESIHRMS: calcd for $\mathrm{C}_{9} \mathrm{H}_{12} \mathrm{O}_{2}$ ， $m / z 153.0910(\mathrm{M}+\mathrm{H})^{+}$, found 153.0916. 


\subsection{Microorganisms}

The fungal and yeast strains used for biotransformation were obtained from the collection of the Department of Chemistry, Wrocław University of Environmental and Life Sciences. They were: Fusarium culmorum AM10, Fusarium avenaceum AM11, Fusarium oxysporum AM13, Fusarium tricinctum AM16, Fusarium semitectum AM20, Fusarium oxysporum AM21, Fusarium equiseti AM22, Fusarium solani AM203, Penicillium vermiculatum AM30, Penicillium camembertii AM83, Penicillium chermesinum AM113, Penicillium frequentans AM351, Absidia cylindrospora AM336, Absidia corerulea AM93, Aspergillus ochraceus AM456, Aspergillus wenthi AM413, Syncephalastrum racemosum AM105, Pleurotus ostreatus AM482, Pleurotus ostreatus AM600, Mucor hiemalis AM450, Yarrovia lipolytica AM71, and Rhodotorula marina AM77. The fungal and yeast strains were cultivated on Sabouraud agar.

\subsubsection{Screening Procedure}

The fungal strains were cultivated in $300 \mathrm{~mL}$ Erlenmayer flasks, containing $100 \mathrm{~mL}$ of the medium consisting of glucose $(3 \mathrm{~g})$ and peptobac $(1 \mathrm{~g})$. After three days when the culture was grown, $10 \mathrm{mg}$ of the substrate dissolved in $1 \mathrm{~mL}$ of acetone was added to each flask. The incubation of the shaken cultures with the substrate was continued for 7 days. After 3, 5, and 7 days of incubation, the medium contained the unreacted substrate, and the product and mycelium were extracted with dichloromethane (15 mL) and analyzed by GC (DB-17 column).

\subsubsection{Preparative Biotransformation}

Reactions were conducted in ten $300 \mathrm{~mL}$ Erlenmayer flasks containing 3-day cultures of fungal or yeast strain (prepared similarly as described above). In this case, $100 \mathrm{mg}$ of substrate was dissolved in $10 \mathrm{~mL}$ acetone and added to ten flasks. After 7 days the post-reaction mixture was extracted with dichloromethane $(3 \times 40 \mathrm{~mL})$. The combined organic fractions were dried over anhydrous magnesium sulphate and the solvent was evaporated in vacuo. Pure product was separated from the unreacted substrate and the metabolites of the fungi or yeast by using column chromatography (silica gel, hexane: acetone 3:1). As an effect of these reactions, four products were obtained, more Data can be found in the Supplementary Materials.

2-Hydroxy-6-methyl-9-oxabicyclo[4.3.0]nonan-8-one (7): m.p. $=68-69{ }^{\circ} \mathrm{C},{ }^{1} \mathrm{H}-\mathrm{NMR}\left(600 \mathrm{MHz}, \mathrm{CDCl}_{3}\right)$ : $1.21\left(\mathrm{~s}, 3 \mathrm{H}, \mathrm{CH}_{3}-9\right), 1.42-1.47\left(\mathrm{~m}, 2 \mathrm{H}\right.$, one of $\mathrm{CH}_{2}-4$ and one of $\left.\mathrm{CH}_{2}-5\right), 1.57-1.59\left(\mathrm{~m}, 1 \mathrm{H}\right.$, one of $\left.\mathrm{CH}_{2}-3\right)$, 1.71-1.74 (m, 1H, one of $\left.\mathrm{CH}_{2}-4\right), 1.81-1.84\left(\mathrm{~m}, 1 \mathrm{H}\right.$, one of $\left.\mathrm{CH}_{2}-3\right), 2.12(\mathrm{~m}, 1 \mathrm{H}, \mathrm{OH}), 2.37(\mathrm{~d}, J=16.5 \mathrm{~Hz}$, $1 \mathrm{H}$, one of $\left.\mathrm{CH}_{2}-7\right), 2.45\left(\mathrm{~d}, J=16.5,1 \mathrm{H}\right.$, one of $\left.\mathrm{CH}_{2}-7\right), 3.84(\mathrm{dt}, J=10.6$ and $4.0 \mathrm{~Hz}, 1 \mathrm{H}, \mathrm{H}-2), 4.24$ $(\mathrm{d}, J=3.3 \mathrm{~Hz}, 1 \mathrm{H}, \mathrm{H}-1),{ }^{13} \mathrm{C}-\mathrm{NMR}\left(151 \mathrm{MHz}, \mathrm{CDCl}_{3}\right): 19.18$ (C-4), 22.32 (C-9), 28.99 (C-3), 32.46 (C-5), 40.10 (C-6), 45.13 (C-7), 67.72 (C-2), 86.12 (C-1), 176.07 (C-8), IR (KBr, cm ${ }^{-1}$ ): 3352, 2938, 1773, 1458, 1201, 1065, 988, ESIHRMS: calcd for $\mathrm{C}_{9} \mathrm{H}_{14} \mathrm{O}_{3}, m / z 171.1016(\mathrm{M}+\mathrm{H})^{+}$, found 171.1021 .

2-Chloro-5-hydroxy-6-methyl-9-oxabicyclo[4.3.0]nonan-8-one (8): colourless oil, ${ }^{1} \mathrm{H}-\mathrm{NMR}$ (600 MHz, $\left.\mathrm{CDCl}_{3}\right): 1.37\left(\mathrm{~s}, 3 \mathrm{H}, \mathrm{CH}_{3}-9\right), 1.73\left(\mathrm{ddd}, J=12.7,8.1\right.$ and $4.0 \mathrm{~Hz}, 1 \mathrm{H}$, one of $\left.\mathrm{CH}_{2}-4\right), 1.98-2.04(\mathrm{~m}$, $1 \mathrm{H}$, one of $\left.\mathrm{CH}_{2}-4\right), 2.12-2.15\left(\mathrm{~m}, 2 \mathrm{H}, \mathrm{CH}_{2}-3\right), 2.38\left(\mathrm{~d}, J=17.2 \mathrm{~Hz}, 1 \mathrm{H}\right.$, one of $\left.\mathrm{CH}_{2}-7\right), 2.79(\mathrm{~d}, J=17.2$, $1 \mathrm{H}$, one of $\left.\mathrm{CH}_{2}-7\right), 3.63(\mathrm{dd}, J=10.7$ and $3.8 \mathrm{~Hz}, 1 \mathrm{H}, \mathrm{H}-5), 4.34-4.36(\mathrm{~m}, 1 \mathrm{H}, \mathrm{H}-2), 4.46(\mathrm{~d}, J=3.2 \mathrm{~Hz}, 1 \mathrm{H}$, $\mathrm{H}-1),{ }^{13} \mathrm{C}-\mathrm{NMR}\left(151 \mathrm{MHz}, \mathrm{CDCl}_{3}\right): 17.07$ (C-9), 24.70 (C-4), 27.84 (C-3), 41.94 (C-7), 43.69 (C-6), 53.99 (C-2), 70.79 (C-5), 86.77 (C-1), 174.16 (C-8), IR (KBr, cm $\left.{ }^{-1}\right)$ : 3434, 2954, 1759, 1437, 1073, 999, ESIHRMS: calcd for $\mathrm{C}_{9} \mathrm{H}_{13} \mathrm{ClO}_{3}, m / z 205.0626(\mathrm{M}+\mathrm{H})^{+}$, found 205.0639 .

2-Bromo-5-hydroxy-6-methyl-9-oxabicyclo[4.3.0]nonan-8-one (9): colourless oil, ${ }^{1} \mathrm{H}-\mathrm{NMR}(600 \mathrm{MHz}$, $\left.\mathrm{CDCl}_{3}\right): 1.41\left(\mathrm{~s}, 3 \mathrm{H}, \mathrm{CH}_{3}-9\right), 1.75\left(\mathrm{ddd}, J=13.0,8.4\right.$ and $4.2 \mathrm{~Hz}, 1 \mathrm{H}$, one of $\left.\mathrm{CH}_{2}-4\right), 1.99-2.04(\mathrm{~m}$, $1 \mathrm{H}$, one of $\left.\mathrm{CH}_{2}-4\right), 2.20-2.22\left(\mathrm{~m}, 2 \mathrm{H}, \mathrm{CH}_{2}-3\right), 2.36\left(\mathrm{~d}, J=17.2 \mathrm{~Hz}, 1 \mathrm{H}\right.$, one of $\left.\mathrm{CH}_{2}-7\right), 2.79(\mathrm{~d}, J=17.2$, $1 \mathrm{H}$, one of $\left.\mathrm{CH}_{2}-7\right), 3.65(\mathrm{dd}, J=10.3$ and $3.0 \mathrm{~Hz}, 1 \mathrm{H}, \mathrm{H}-5), 4.37-4.39(\mathrm{~m}, 1 \mathrm{H}, \mathrm{H}-2), 4.58(\mathrm{~d}, J=3.5 \mathrm{~Hz}$, 1H, H-1), ${ }^{13} \mathrm{C}-\mathrm{NMR}\left(151 \mathrm{MHz}, \mathrm{CDCl}_{3}\right.$ ): 17.95 (C-9), 25.68 (C-4), 28.49 (C-3), 41.82 (C-7), 44.00 (C-6), 
45.21 (C-2), 70.68 (C-5), 87.22 (C-1), 174.09 (C-8), IR (KBr, cm ${ }^{-1}$ ): 3427, 2953, 1772, 1434, 1220, 1074, 992, ESIHRMS: calcd for $\mathrm{C}_{9} \mathrm{H}_{13} \mathrm{BrO}_{3}, m / z 249.0121(\mathrm{M}+\mathrm{H})^{+}$, found 249.0130 .

5-Hydroxy-2-iodo-6-methyl-9-oxabicyclo[4.3.0]nonan-8-one (10): m.p. $=58-59{ }^{\circ} \mathrm{C},{ }^{1} \mathrm{H}-\mathrm{NMR}(600 \mathrm{MHz}$, $\left.\mathrm{CDCl}_{3}\right): 1.47\left(\mathrm{~s}, 3 \mathrm{H}, \mathrm{CH}_{3}-9\right), 1.76-1.80\left(\mathrm{~m}, 1 \mathrm{H}\right.$, one of $\left.\mathrm{CH}_{2}-4\right), 1.91-1.97\left(\mathrm{~m}, 1 \mathrm{H}\right.$, one of $\left.\mathrm{CH}_{2}-4\right), 2.12-2.17$ $\left(\mathrm{m}, 1 \mathrm{H}\right.$, one of $\left.\mathrm{CH}_{2}-3\right), 2.25-2.29\left(\mathrm{~m}, 1 \mathrm{H}\right.$, one of $\left.\mathrm{CH}_{2}-3\right), 2.32\left(\mathrm{~d}, J=17.1 \mathrm{~Hz}, 1 \mathrm{H}\right.$, one of $\left.\mathrm{CH}_{2}-7\right), 2.45(\mathrm{~d}$, $J=17.1,1 \mathrm{H}$, one of $\left.\mathrm{CH}_{2}-7\right), 3.71(\mathrm{dd}, J=9.6$ and $3.6 \mathrm{~Hz}, 1 \mathrm{H}, \mathrm{H}-2), 4.44(\mathrm{dd}, J=9.1$ and $4.4 \mathrm{~Hz}, 1 \mathrm{H}$, one of $\left.\mathrm{CH}_{2}-5\right), 4.69(\mathrm{~d}, J=4.0 \mathrm{~Hz}, 1 \mathrm{H}, \mathrm{H}-1),{ }^{13} \mathrm{C}-\mathrm{NMR}\left(151 \mathrm{MHz}, \mathrm{CDCl}_{3}\right): 19.09$ (C-9), 22.53 (C-5), 28.03 (C-4), 30.64 (C-3), 42.00 (C-7), 44.77 (C-6), 71.10 (C-2), 89.20 (C-1), 174.16 (C-8), IR (KBr, cm ${ }^{-1}$ ): 3427, 2929, 1754, 1437, 1224, 1066, 977, ESIHRMS: calcd for $\mathrm{C}_{9} \mathrm{H}_{13} \mathrm{IO}_{3}, m / z 296.9982(\mathrm{M}+\mathrm{H})^{+}$, found 296.9988 .

\subsection{Bioassay Tests on Microorganisms}

In this step the following bacteria strains were used: Escherichia coli $\mathrm{C} 1$, Staphylococcus aureus, Bacillus subtilis B5, yeast strains: Candida albicans KL-1 and filamentous fungi strains: Aspergillus niger XP, Fusarium linii 3A, Penicillium sp., Alternaria sp. The bacteria strains were obtained from the collection of the Department of Biotechnology and Food Microbiology, Wrocław University of Environmental and Life Sciences. The test were performed in the automated Bioscreen C system (Automated Growth Curve Analysis System, Lab Systems, Helsinki, Finland) with a procedure analogous to the one described before [15].

\subsection{Aphid Settling Bioassays}

The test were performed according to a procedure analogous to the one described before [17].

\section{Conclusions}

Four lactones were obtained from an $\gamma, \delta$-unsaturated carboxylic acid via Claisen rearrangements. The four compounds were subjected to a screening biotransformation using twenty fungal strains and two yeast strains. Only some of them, namely F. equiseti AM22, F. solani AM203, P. camembertii AM83, A. cylindrospora AM336, S. racemosum AM105, and Y. lipolytica AM71, were able produce a hydrolytic dehalogenation of the halolactones, giving as a product the hydroxylactone 7 . Additionally the P. vermiculatum AM30 strain gave other products-the new hydroxyhalolactones 8-10. Hydroxylactone $\mathbf{7}$ was preferentially formed as a (-)-isomer, while in the case of hydroxy-halolactones $\mathbf{8 - 1 0}$, a (+)-isomer was preferred. The biological tests proved that lactones mostly inhibit bacteria strains (E. coli and S. aureus). A similar effect was observed for the F. avenaceum strain (for lactones 4 and 5). On the other hand, in the case of the $C$. albicans and the F. avenaceum strains, the tested lactones 7 and 6,7 caused a stimulation of biomass growth. Biological assays conducted on M. persicae showed that lactones 4 and 5 possesses the best deterrent activity. The unsaturated lactone 6 also showed feeding deterrent activity, but the strongest effect only lasted for two hours. Unexpectedly, hydroxylactone 7 was an attractant during the first hour and then its activity changed to a weak deterrent.

Supplementary Materials: The following are available online at http://www.mdpi.com/1420-3049/21/11/1453/s1.

Acknowledgments: Publication supported by the Wroclaw Centre of Biotechnology under the Leading National Research Centre (KNOW) programme for years 2014-2018.

Author Contributions: Katarzyna Wińska conceived and designed the experiments and analyzed the data; Katarzyna Wińska and Wanda Maczka performed the experiments; Katarzyna Wińska and Małgorzata Grabarczyk wrote the paper; Barbara Żarowska, Katarzyna Dancewicz and Beata Gabryś performed the biological analysis; Gabriela Maciejewska performed the high resolution mass spectrometry analysis; Antoni Szumny and Małgorzata Grabarczyk analyzed NMR spectrum of products; and Mirosław Anioł contributed to the discussion of results. All authors read and approved the final manuscript.

Conflicts of Interest: The authors declare no conflict of interest. 


\section{References}

1. Scher, R.K.; Nakamura, N.; Tavakkol, A. Luliconazole: A review of a new antifungal agent for the topical treatment of onychomycosis. Mycoses 2014, 57, 389-393. [CrossRef] [PubMed]

2. Moussa, Z.; El-Sharief, M.A.; El-Sharief, A.M. Synthesis and characterization of new types of halogenated and alkylated imidazolidineiminothiones and a comparative study of their antitumor, antibacterial, and antifungal activities. Eur. J. Med. Chem. 2011, 46, 2280-2289. [CrossRef] [PubMed]

3. Vairappan, C.S.; Kawamoto, T.; Miwa, H.; Suzuki, M. Potent antibacterial activity of halogenated compounds against antibiotic-resistant bacteria. Planta Med. 2004, 70, 1087-1090. [CrossRef] [PubMed]

4. Lakshmanan, K.; Sekar, K.G.; Sathiyendiran, V.; Muthuvel, I. Insect antifeedant potent quinoxalines. Int. Lett. Chem. Phys. Astron. 2015, 2, 82-87. [CrossRef]

5. Boulogne, I.; Petit, P.; Ozier-Lafontaine, H.; Desfontaines, L.; Loranger-Merciris, G. Insecticidal and antifungal chemicals produced by plants: A review. Environ. Chem. Lett. 2012, 10, 325-347. [CrossRef]

6. Zhenchuk, A.; Lotfi, K.; Juliusson, G.; Albertioni, F. Mechanisms of anti-cancer action and pharmacology of clofarabine. Biochem. Pharmacol. 2009, 78, 1351-1359. [CrossRef] [PubMed]

7. Bossert, I.D.; Häggblom, M.M.; Young, L.Y. Microbial ecology of dehalogenation. In Dehalogenation: Microbial Processes and Environmental Applications; Häggblom, M.M., Bossert, I.D., Eds.; Kluwer Academic Publishers: Boston, MA, USA, 2003; pp. 33-52.

8. Vairappan, C.S. Potent antibacterial activity of halogenated metabolites from Malaysian red algae, Laurencia majuscula (Rhodomelaceae, Ceramiales). Biomol. Eng. 2003, 20, 255-259. [CrossRef]

9. Ren, D.; Wood, T.K. (5Z)-4-bromo-5-(bromomethylene)-3-butyl-2(5H)-furanone reduces corrosion from Desulfotomaculum orientis. Environ. Microbiol. 2004, 6, 535-540. [CrossRef] [PubMed]

10. Vairappan, C.S.; Ishii, T.; Lee, T.K.; Suzuki, M.; Zhaoqi, Z. Antibacterial activities of a new brominated diterpene from Borneon Laurencia spp. Mar. Drugs 2010, 8, 1743-1749. [CrossRef] [PubMed]

11. Jensen, S.R.; Gotfredsen, C.H.; Harput, U.S.; Saracoglu, I. Chlorinated iridoid glucosides from Veronica longifolia and their antioxidant activity. J. Nat. Prod. 2010, 73, 1593-1596. [CrossRef] [PubMed]

12. Nenkep, V.; Yun, K.; Zhang, D.; Choi, H.D.; Kang, J.S.; Son, B.W. Induced production of bromomethylchlamydosporols A and B from the marine-derived fungus Fusarium tricinctum. J. Nat. Prod. 2010, 73, 2061-2063. [CrossRef] [PubMed]

13. Yin, S.; Boyle, G.M.; Carroll, A.R.; Kotiw, M.; Dearnaley, J.; Quinn, R.J.; Davis, R.A. Caelestines A-D, Brominated quinolinecarboxylic acids from the Australian ascidian Aplidium caelestis. J. Nat. Prod. 2010, 73, 1586-1589. [CrossRef] [PubMed]

14. Yang, X.; Davis, R.A.; Buchanan, M.S.; Duffy, S.; Avery, V.M.; Camp, D.; Quinn, R.J. Antimalarial bromotyrosine derivatives from the Australian marine sponge Hyattella sp. J. Nat. Prod. 2010, 73, 985-987. [CrossRef] [PubMed]

15. Sobczak, A. Czynniki chemiczne w środowisku zagrażające zdrowiu ludzi. Environ. Med. 2012, 15, 7-17.

16. Grabarczyk, M.; Mączka, W.; Wińska, K.; Żarowska, B.; Anioł, M. Antimicrobial activity of hydroxylactone obtained by biotransformation of bromo- and iodolactone with gem-dimethylcyclohexane ring. J. Braz. Chem. Soc. 2013, 24, 1913-1919. [CrossRef]

17. Grabarczyk, M.; Wińska, K.; Mączka, W.; Żarowska, B.; Maciejewska, G.; Dancewicz, K.; Gabryś, B.; Anioł, M. Synthesis, biotransformation and biological activity of halolactones obtained from $\beta$-ionone. Tetrahedron 2016, 72, 637-644. [CrossRef]

18. Grabarczyk, M.; Wińska, K.; Mączka, W.; Żołnierczyk, A.K.; Żarowska, B.; Anioł, M. Lactones with methylcyclohexane system obtained by chemical and microbiological methods and their antimicrobial activity. Molecules 2015, 20, 3335-3353. [CrossRef] [PubMed]

19. Monod, J. The growth of bacterial cultures. Annu. Rev. Microbiol. 1949, 3, 371-394. [CrossRef]

20. Naranga, A.; Pilyugin, S.S. Bacterial gene regulation in diauxic and non-diauxic growth. J. Theor. Biol. 2007, 244, 326-348. [CrossRef] [PubMed]

21. Loomis, W.F., Jr.; Magasanik, B. Glucose-Lactose Diauxie in Escherichia coli. J. Bacteriol. 1967, 93, $1397-1401$. [PubMed]

22. Grudniewska, A.; Dancewicz, K.; Białońska, A.; Ciunik, Z.; Gabryś, B.; Wawrzeńczyk, C. Synthesis of piperitone-derived halogenated lactones and their effect on aphid probing, feeding, and settling behavior. RSC Adv. 2011, 1, 498-510. [CrossRef] 
23. Grudniewska, A.; Dancewicz, K.; Białońska, A.; Wawrzeńczyk, C.; Gabryś, B. Piperitone-derived saturated lactones: Synthesis and aphid behavior-modifying activity. J. Agric. Food Chem. 2013, 61, 3364-3372. [CrossRef] [PubMed]

24. Grudniewska, A.; Kłobucki, M.; Dancewicz, K.; Szczepanik, M.; Gabryś, B.; Wawrzeńczyk, C. Synthesis and antifeedant activity of racemic and optically active hydroxy lactones with the p-menthane system. PLoS ONE 2015, 10, 1-17. [CrossRef] [PubMed]

25. Burgstahler, A.W.; Nordin, I.C. Specyfic angular alkylation. A new application of the Claisen rearrangement. J. Am. Chem. Soc. 1961, 83, 198-206. [CrossRef]

26. Grabarczyk, M.; Białońska, A. Biotransformations of chloro-, bromo- and iodolactone with trimethylcyclohexane system using fungal strains. Biocatal. Biotransform. 2010, 5-6, 408-414. [CrossRef]

27. Grabarczyk, M.; Szumny, A.; Gładkowski, W.; Białońska, A.; Ciunik, Z.; Wawrzeńczyk, C. Lactones 18. Synthesis of bicyclic lactones with methyl-, di- and trimethyl substituted cyclohexane system. Polish J. Chem. 2005, 79, 1763-1771. [CrossRef]

Sample Availability: Samples of the compounds 1-10 are available from the authors.

(C) 2016 by the authors; licensee MDPI, Basel, Switzerland. This article is an open access article distributed under the terms and conditions of the Creative Commons Attribution (CC-BY) license (http://creativecommons.org/licenses/by/4.0/). 